\title{
Tele-education and Competencies Assessment to Brazilian's auxiliary nurse
}

\author{
A TELE-EDUCAÇÃO E A AVALIAÇÃO DE COMPETÊNCIAS PROFISSIONAIS \\ DA AUXILIAR DE ENFERMAGEM NO BRASIL
}

\section{LA TELE-EDUCACIÓN Y LA EVALUACIÓN DE COMPETENCIAS PROFESIONALES DE LOS AUXILIARES DE ENFERMERÍA EN BRASIL}

\section{Claudia Maria da Silva Marques', Emiko Yoshikawa Egry², Maria Bonifácio Silva ${ }^{3}$, Maria Cecília Ribeiro4, Marta Pazos Peralba Coelho ${ }^{5}$, Rosa Maria Godoy Serpa da Fonseca ${ }^{6}$, Teresa Christina Pereira Morais ${ }^{7}$}

\begin{abstract}
This paper presents Brazilian's experience with the organization of methods and strategies for the assessment of competencies for technical level of nursing workers. The evaluative process proposed includes the creation of a learningoriented and distance-based virtual assessment environment. The proposed methodology for professional competencies assessment adopted a critical-emancipatory perspective. A tele-education environment was deployed, involving software development - a virtual man - and an assessment cybertutor. Learning modules for the cybertutor were developed and videos of clinical simulations, structured around assessment in cognitive, behavioral, and simulation areas. The evaluation modules considered aspects of competencies in know-know, know-how and knowact professional ethics. Also the variability of practices of nursing hospitals and primary health care units - was considered. This instrument showed as an important strategy for the optimization of assessment procedures that are widely used across Brazil and it is a powerful tool for incorporation into the continuing professional education.
\end{abstract}

\section{KEY WORDS}

Professional competency.

Evaluation.

Educational technology.

Nurses'aides.

\section{RESUMO}

Este trabalho apresenta a experiência brasileira na organização de metodologias e estratégias de avaliação de competências profissionais do auxiliar de enfermagem. $\mathrm{O}$ processo avaliativo proposto pelo Ministério da Saúde inclui, além de outras etapas, a criação do ambiente virtual de avaliação, que tem como premissa a avaliação formativa e à distância. Dentro da proposta metodológica de avaliação de competências profissionais na perspectiva crítico-emancipatória, foi desenvolvido um ambiente de tele-educação, com a criação de softwares, do homem virtual e do cybertutor de avaliação. Os módulos de avaliação consideraram as competências nas dimensões do saber-saber, saber-fazer e saberser, baseado em perfil profissional das praticas hospitalares e de unidades básicas de saúde. O instrumento mostrou ser uma importante estratégia de otimização dos procedimentos de avaliação para uso em larga escala no Brasil, além de um instrumento importante para educação permanente.

\section{RESUMEN}

Presenta-se la experiencia brasileña en la organización de metodología y estrategias de evaluación de las competencias profesionales de los afiliares de enfermería. El proceso evaluativo propuesto por el Ministerio de la Salud incluí la creación del ambiente virtual que tiene como premisa la evaluación formativa y à la distancia. Dentro de la propuesta metodológica de evaluación de las competencias profesionales en la perspectiva critico-emancipatória, fue desarrollado un ambiente de tele-educación, con la creación de software, del hombre virtual y del cybertutor de la evaluación. Los módulos de evaluación consideraran las competencias en las dimensiones del saber-saber, saber-hacer y saber-ser, con bases en perfil de los profesionales de los hospitales y de unidades de salud. El instrumento mostró ser una importante estrategia de optimización de los procedimientos de evaluación para uso en larga escala en Brasil, además de se mostrar un potente medio de educación permanente.
1 Brazilian Ministry of Health. Coordinator of the System of Competency Certification. Master in Collective Health Nursing

cmmarques@usp.br

2 Doctor of Public

Health. Professor in the Department of Nursing in Collective Health at the School of Nursing,

University of São

Paulo. Brazilian Ministry of Health Consultant

3 Brazilian Ministry of Health. Technical Advisor.

4 Brazilian Ministry of Health. Technical Advisor.

5 Brazilian Ministry of Health. Technical Advisor.

6 Doctor of Nursing.

Professor in the Department of Nursing in Collective Health at the School of Nursing,

University of São Paulo. Brazilian Ministry of Health Consultant.

7 Brazilian Ministry of Health. Technical Advisor.

\section{DESCRITORES}

Competência profissional.

Avaliação.

Tecnologia educacional.

Auxiliares de enfermagem.

\section{DESCRIPTORES}

Competencia profesional.

Evaluación.

Tecnología educacional.

Auxiliares de enfermería. 


\section{INTRODUCTION}

The regulation of human resources forms part of the political and institutional responsibility of the Brazilian Ministry of Health. In this sense, the Nursing Workers Professionalization Project (NWPP) was implemented in 2000 with the objective of certifying workers in the area of nursing who practice the profession outside of its regular structures, in terms of education, professional ethics or working conditions, within the public and private sectors of the Unified Health System (UHS) ${ }^{(1)}$. Meanwhile, NWPP has created the conditions for the continuance and sustainability of technical-level educational programs, in an effort to guarantee the quality of nursing care and to prevent a new contingent of irregular works from arising in the future. To implement these goals, the Project developed two lines of action: (1) a reduction in the lack of nursing assistants qualified to work in the sector and (2) a reinforcement of the normative pattern and regulation of health care, with the establishment of the technical and financial conditions for sustaining technical education in health, especially in nursing. Examples of this include the development of an Educational Pedagogy Program for Nursing Instructors, the development of strategies to strengthen SUS's Technical Schools, and the development of a means to identify profiles of professional competencies and to evaluate these competencies ${ }^{(2)}$.

The pedagogical relevance of the project is showed in the conception of assessment adopted as a primarily educational perspective, and the principal aim is to improve the process of learning for all who are involved - students, teachers, educators and educational institutions. The incorporation of this System into NWPP therefore took up the challenge of demonstrating the possibility and importance of a professional certification process that is tied to professional education and learning-oriented assessment, developing methods that might flag important indexes of assessment and reorientation, as much for education as for the service sector of health services, with the ongoing aim of developing future measures for the professional certification of healthcare workers in $\mathrm{Brazil}^{(2)}$.

NWPP has created a model of evaluation in which the actions - learning-assessment-certification-learning - is a continuing spiral, in the sense of lifelong and continuous education. The link between education and professional certification is considered vital to ensuring that professionals who have not obtained certification due to a lack of experience or appropriate educational qualifications and they will have the opportunity to access continuous education. This link is a key means of preventing exclusion ${ }^{(2)}$.
Certification is a strategy of management and this model, as defined by the Ministry of Health, requires profound changes in the organization of the workforce and education sectors because the changes of the conception of health care. According to UHS ${ }^{(1)}$ health-illness process depends on the quality of life, which gives rise to such concepts as teamwork and interdisciplinarity and cooperation between different sectors. To make health requires professionals able to work in different areas in order to promote an improvement in health indicators at all level of care: primary, secondary and tertiary ${ }^{(2)}$.

The NWPP professional certification has important proposals: it is an instrument to introduce a politics of health defined by the sector and by new forms of organization in health services; it gives advice on the design of programs and educational curricula at the technical level, thereby facilitating the possibility of lifelong education and yielding a means of gauging workers' deficiencies; and it provides workers with a recognition of their abilities, as well as the possibility and opportunity to complement them, or correct them, or improve them ${ }^{(3)}$.

In addition, the NWPP system is pioneering and innovative: new in the healthcare sector, involving methods and strategies adapted to the specificities and scope of a regu-lated profession, and allowing for the incorporation of the realities of the workplace into the educational process. And it's not restricted the competencies as a mere list of duties. This conceptual frame has developed a concept of competence that is linked to the work spaces where healthcare takes place and to its procedures, to new conceptions of service that considerer the professionals as part of a team, providing them with opportunities to develop their pro-fessional profile $^{(2)}$.

The professional competencies identified for auxiliary nurses therefore are based on the idea of a human competence for health work, which expresses itself in the capacity of one human to help another, to activate the knowledge necessary to prevent and resolve health problems, through the mobilization and utilization of technologies key to the act of healing $^{(3)}$. Thus, the principal outcomes of the NWPP were as follows: the elaboration of critical-emancipatory methods: to the identify profiles of professional competencies and to construct and validate a learning-oriented evaluation of competencies model ${ }^{(3)}$.

\section{OBJECTIVES}

- To present the framework and concept of assessment developed by the Brazilian Ministry of Health. 
- To show the results of the application of tele-education to processes of professional competency assessment for auxiliary nurses.

\section{The critical-emancipatory method to evaluate professional competencies}

\section{Theoretical and Methodological Premises}

To develop, to test and to validate a process for professional competencies assessment under the critical-emancipatory process requires strategies that allow the demonstration of competencies when the professional handles problems in practice. In fact, doing this, they can show social visibility of their actions and also visibility of the process of professional education in the preparatory schools.

The fundamental marks that underlie this method of assessment are as follows ${ }^{(4)}$ :

- Health is part and consequence and this health-illness process conception is bases of professional education;

- Brazilian Sanitary Reform and UHS are the main reference of health professional education;

- The development of formal competencies and policies that assure that practitioners have the human competency necessary to health care.

- Competencies can be improved and they are necessary to the work in health care; even the Brazilian practice presents diversity according to different region of the country, it's possible to improve competencies that respect these diversities;

- Brazilian Professional Education Legislation presents similarity with health sector: high value of education and evaluation based on a model of competency, flexible education and continuous and lifelong education;

- A process of evaluation that recognizes and values the real qualifications of the worker, perceived as competencies that extend beyond the cognitive dimension by emphasizing the know-act ethical professional.

This method recognizes the competency much more than simply attesting to knowledge acquired through the formal means of teaching-learning processes. The evaluative process must also incorporate new ways of identifying, promoting and generating the knowledge bases that workers mobilize in order to confront, with initiative and responsibility, situations and events specific to their professional field, thereby enabling their self-development. The assessment procedures must have the potential to incite individuals and institutions to transform their practices ${ }^{(2)}$.

The system of assessment based on competencies is part of a process of learning and must value the application and synthesis of knowledge, combining the capacity to resolve problems, technical abilities and attitudes and ethics. And the process of assessment itself can be learning opportunity for all people involved. Thus it must privilege a dialogue and exchange of the participants' different points of view, aiming to stimulate a critical examination of the results and their interpretations. For this reason, assessment is not restricted to the quantitative level of concepts, notes or classifications. On the contrary, it must allow people to confront problems and situations according to their own style and according to criteria (norms and patterns) that delimit what is a good performance ${ }^{(4)}$.

According to the critical-emancipatory vision, performance is assumed to be a concrete expression of the resources that an individual articulates and mobilizes in confronting situations and events within their professional field. Competency is a condition of performance, being the underlying mechanism which permits the integration of the many types of knowledge and acts necessary to the realization of a task. Performance cannot be reduced to the results or acts done, consisting of the mere completion of defined, codified and prescribed duties, tasks or activities. An evaluation of performance allows for the identification of how a professional articulates or mobilizes capabilities or knowledge when faced with real work situations. It therefore must consider well-defined contexts that permit the identification of situations already experienced by workers or proposed by analogy or correlation ${ }^{(4-5)}$.

In the context of professional education, as considered from NWPP perspective, the evaluation of competencies assumes special characteristics that this evaluation incorporates knowledge in action, through the articulation of skills, abilities and attitudes, acquired not only in formal learning situations but also to great extent in the sphere of work. Thus, professional education must adopt a broader political, social and cultural scope and the role of assessment must expand as well. Assessment should evaluate competencies by observing a person undertake more complex and complete tasks and considering the overall profile of each professional, in terms of competencies and patterns of desired performance, in the larger context described above. All of this results in an expansion beyond the traditional role of evaluation, which has been to verify competency through the mobilization of knowledge ${ }^{(4)}$.

In addition, the endpoint of evaluation is not to make a categorical decision about whether or not someone is competent. To avoid running that risk and to break from such a pragmatic and utilitarian vision of assessment, this method looks to the educative perspective of evaluation. It aims to improve the whole process, rather than simply seeking a final judgment on an individual ${ }^{(5)}$.

Overall, then, the evaluation process seeks to fulfill the following objectives: diagnostic that indicates the potential 
problems faced by students or within the learning process itself; didactic that guides improvement of student performance and of behavior of educational institutions; summative leading that refers to a certification or diploma; and to give responsibility through the involvement of institutions of education and employment in the processes of training and continuous learning for their employees ${ }^{(4)}$.

In seeking to ensure these aims, the evaluation process developed by NWPP employs strategies and methods that bring together the different dimensions of knowledge that make up the competencies, while still guaranteeing the indepth evaluation of each separate area. Thus, from a methodological point of view, the evaluation uses different procedures and instruments that broaden the specific analysis of the range of competencies being assessed. In our case ${ }^{(6-7)}$ we were developed in four phases:

A The objective evaluation of knowledge

B The evaluation of procedures in a virtual environment

$\mathrm{C}$ The evaluation of procedures via simulated practice

D The evaluation of the know-be an ethical professional dimension

The objective evaluation of knowledge was elaborated through the construction of a test guide, reflecting the profile of professional competencies for the auxiliary nurses, and the evaluative power of each question was tested using psychometric. The virtual evaluation was deployed via the internet. It included a description of scenarios, a narrative of user contexts, and a sequence of tasks in hospital and extrahospital environments, in which nursing assistants respond to questions, choose options, and make decisions ${ }^{(7-8)}$.

The practical evaluation had as its principal focus the verification of psychomotor abilities. It examined procedures such as the verification of vital signs and the application of the triple bacterial vaccine or the administration of intramuscular medication packed in an ampoule vial. It took place in a laboratory environment, using mannequins ${ }^{(7)}$.

The decision of what procedures would be evaluated in a simulated practice situation and in a virtual environment were made based on the development of an evaluative matrix that allowed for the identification of the baseline of the bodies of knowledge that make up the competencies, or in other words, those that were most regular, constant, and common. Various factors were considered for this: setting of the production of services (primary care network, hospital, home, mobile units, etc.); forms of intervention, organization and regulation of work; specific clientele being served (adults, women, senior citizens, children, adolescents, etc.); and types and degrees of risk, among others ${ }^{(7)}$.

The evaluation of the know-be an ethical professional component aimed to complement the former assessments, which express the know-know, know-do and know-be an ethical professional components, except that in this phase the emphasis was primarily on the know-be an ethical professional element ${ }^{(9-10)}$.

From the point of view of evaluation methods, this one is the most unusual. This phase was being developed based on data about the real professional lives of auxiliary nurses. Research was undertaken to identify the key aspects of the "know-be an ethical professional" needs of auxiliary nurses, notably ethic-political competencies. After a thematic analysis of the narratives of practice, an evaluative tool was made, with the support of specialists in group dynamics, professional ethics, and bioethics ${ }^{(5,10)}$.

\section{Tele-education applied to the evaluation of competencies}

The conceptualization and construction of a virtual assessment environment were divided into two stages. In the first stage, learning modules for the cyber-tutor were developed; these were integrated with the virtual man and with videos of clinical simulations, structured around assessment in cognitive, behavioral, and simulation areas. In the second stage, technological means of virtual assessment were implemented to support assessment sessions, as well as to collect information for the online monitoring of the assessment process across the country. The project was based on the use of internet technology to integrate the evaluations in a multicentre manner and on the use of the virtual man as a pictorial resource, in three dimensions, for illustration and simulation ${ }^{(6,8,11)}$.

\section{Phase I}

The modules for learning and assessment considered aspects of competency in the areas of know-know, knowhow and know-being professional ethics (including getting along with others) making use of a description of scenes, a narrative of user contexts, and a sequence of nursing duties performed at hospitals and primary health care units. Software was specifically developed for these modules. This phase consisted of the development and validation of the evaluative tools and the implementation of the first assessment module, accompanied by a tutorial guide ${ }^{(6,8,11)}$.

The learning modules and the review of knowledge on the cyber-tutor, along with the learning tools (the virtual man and videos of clinical simulations), were made available in the form of a CD-ROM to the auxiliary nurses and registered nurses evaluators. Modules related to the procedures selected for evaluation were then developed-there were three phases for the tele-education sessions: interactive texts on the cyber-tutor, the evaluation of the process, and clinical case studies. The cyber-tutor made it possible to evaluate the following aspects of the procedures: an objective evaluation of knowledge, an evaluation of reasoning (the 
application of knowledge to the solution of problems) and the evaluation of conduct (the application of knowledge to the choice of actions needed to attend to patients). In addition, the following were made available: a storage area at the Data Center for the programs implemented and the distance assessments; a video-streaming resource (based on the Internet) with the ability to connect up to 15 remote points and to expand the assessors' reach; and the implementation of a center for monitoring the auxiliary nurses who participated in the process of evaluation ${ }^{(6)}$.

\section{Phase II}

Phase II involved the expansion of the evaluative tool and of learning devices (the virtual man and videos of clinical simulations) for additional procedures chosen as objects of virtual assessment.

- The promotion of a multicentre access capacity for assessors by means of videoconferencing in three Brazilian cities with video-streaming transmission to more than 15 online access points.

- The implementation of the technical resources for virtual evaluation to support the evaluation sessions, with the participation of 792 auxiliary nurses.

- The implementation of supervisory reporting modules for the online monitoring of the evaluation process in different parts of the country.

\section{CONCLUSIONS}

Virtual assessment by means of software, the cyber-tutor and above all the pictorial resources of illustration and simulation - the virtual man - form components of the pedagogic process, whose principal aim is to facilitate learning. In this respect, it effectively contributes not only to the valorization of cognitive abilities, but also to the interchange between having, applying, and systematizing knowledge to the resolution of problems to the making and justifying decisions ${ }^{(12)}$.

This instrument, by offering a large quantity of programs for distance learning and assessment, via modern technologies of computing and telecommunications, has proved to be an important strategy for the optimization of simultaneous assessment in geographically disparate parts of the country, optimizing the work of instructors and central coordinators.

The tools deployed via the Internet allowed for the online consolidation of data and the production of statistical reports about the way the evaluations were conducted; auxiliary nurses could access, on the site, comments about their responses and discuss their results. One of the outcomes of this process has been to encourage healthcare workers to use digital resources, especially at the technical level, and to make use of tele-medicine and tele-education. And theses competencies can promote health in collective perspective, improving Unified Health System as well ${ }^{(13)}$. Another outcome has to do with the conditions of evaluation defined by NWPP, principally in terms of: reinforcing its learning function, as a means to help students or workers in studying procedures and techniques central to their professional practice; identifying the weaknesses in their education; understanding what will allow them to successfully attain the competencies required by the profession; stimulating an attitude towards evaluation among institutions of learning that will encourage them to improve their teaching and the ways their curricula are organized. Finally, the development of this assessment instrument demonstrates the viability the process that is tied to professional education and learning-oriented evaluation.

\section{REFERENCES}

1. Brasil. Lei n. 8.080, de 19 de setembro de 1990. Lei Orgânica da Saúde. Dispõe sobre a Promoção, Proteção e Recuperação da Saúde, a Organização e o Funcionamento dos Serviços Correspondentes e dá outras providências [legislação na Internet]. Brasília; 1990. [citado 2007 jun. 25]. Disponível em: http:// internatorural.medicina.ufmg.br/lei_08.pdf

2. Brasil. Ministério da Saúde. Secretaria de Gestão do Trabalho e da Educação na Saúde. Referências conceituais para a organização do sistema de certificação de competências/ PROFAE. Brasília; 2000.

3. Brasil. Ministério da Saúde. Secretaria de Gestão do Trabalho e da Educação na Saúde. Perfil de competências do auxiliar de enfermagem/ PROFAE. Brasília; 2003.
4. Brasil. Ministério da Saúde. Secretaria de Gestão do Trabalho e da Educação na Saúde. Relatório final da validação do perfil de ações do auxiliar de enfermagem/ PROFAE. Brasília; 2001.

5. Egry EY, Marques CMS, Fonseca RMGS. A avaliação de competências na perspectiva crítico-emancipatória. Ciênc Cuidado Saúde. 2006;5(2):238-44.

6. Brasil. Ministério da Saúde. Secretaria de Gestão do Trabalho e da Educação na Saúde. Desenvolvimento da Tele-educação para o processo de avaliação de competências profissionais das auxiliares de enfermagem egressos do PROFAE. Brasília; 2005.

7. Brasil. Ministério da Saúde. Secretaria de Gestão do Trabalho e da Educação na Saúde. Planejamento estratégico da validação de metodologia de avaliação 1 de competências profissionais do auxiliar de enfermagem egressos do PROFAE. Brasília; 2005. 
8. Chao LW. Modelo de ambulatório virtual (cyberambultório) e tutor eletrônico (cybertutor) para aplicação na interconsulta médica, e educação à distância mediada por tecnologia [tese]. São Paulo: Faculdade de Medicina, Universidade de São Paulo; 2003.

9. Brasil. Ministério da Saúde. Secretaria de Gestão do Trabalho e da Educação na Saúde. Documento filosófico-conceitual de referencias para o processo de avaliação de competências profissionais dos auxiliares de enfermagem egressos dos cursos do PROFAE, para a dimensão do saber-ser. Brasília; 2005.

10. Egry EY, Fonseca RMGS. A prática de enfermagem nos cenários na era do Sistema Único de Saúde. In: Kalinowski CE, organizador. PROENF - Programa de Enfermagem: saúde do adulto. Módulo 1. Porto Alegre: Artmed; 2006. p. 11-42.
11. Homem Virtual: Universidade desenvolve CD-ROMs com imagens detalhadas do corpo humano em três dimensões. Isto É. 2003 nov. 19;(1781):50.

12. Marques CMS. A certificação de competências profissionais: o que o PROFAE está pensando e fazendo. Formação. 2001; 2(1):56-60.

13. Silva CV, Egry EY. Constituição de competências para a intervenção no processo saúde-doença da população: desafio ao educador de enfermagem. Rev Esc Enferm USP. 2003;37 (2):11-6.

\section{The authors thanks to the colleagues that contributed to built this Project:}

Mrs. Izabel dos Santos

Brazilian Ministry of Health. Office for the Administration of Labor and Health Education. PROFAE' Consultant

Mrs. Ena de Araújo Galvão

Brazilian Ministry of Health. General Coordinator of Technical Operations for Professional Health Education. Office for the Administration of Labor and Health Education.

Mrs. Luzia da Silva

Brazilian Ministry of Health. Consultant with PROFAE Office for the Administration of Labor and Health Education. PROFAE' Consultant

Prof. Dr. Chao Lung Wen

Associate Professor of Medicine Faculty of São Paulo University. 